\title{
Serum aspartate and alanine transaminase levels in workers exposed to lead
}

\author{
H. A. WALDRON \\ From the Medical Department, Vauxhall Motors Ltd.
}

SYNOPSIS Serum aspartate and alanine transaminase levels were studied in a group of 46 workers exposed to lead. In none of them did the level of either enzyme vary from the values found in a group of 50 healthy persons with no industrial exposure to lead. No correlation was found between levels of aspartate transaminase or alanine transaminase and blood lead concentrations.

Raised levels of serum aspartate transaminase, formerly known as glutamic oxalacetic transaminase, ${ }^{1}$ were reported in 25 persons exposed to industrial lead by Waldman and Borman (1959). This finding was accompanied in many cases by a raised blood lead level, although the relationship between the blood lead level and the aspartate transaminase level was not a fully quantitative one. Casula, Cherchi, Piredda, and Spinazzola (1959), however, reported finding normal levels of both serum aspartate and alanine transaminase (previously called glutamic pyruvic transaminase) in cases of chronic saturnism.

In the face of these apparently conflicting results, it was decided to investigate the serum aspartate and alanine transaminase levels amongst a group of 46 lead workers employed in this factory. All the men examined had been exposed to lead in some degree for at least 11 months, most having worked with lead for five or more years. None of them had any clinical evidence of lead poisoning. A group of 50 healthy workers with no industrial exposure to lead was taken as a control sample.

\section{METHODS}

Serum aspartate and alanine transaminases were estimated by the method of Reitman and Frankel (1957) and the results are expressed in international units/litre. Blood lead was estimated using the method described by King and Thompson (1961).

\section{RESULTS}

The results of the enzyme estimations are set out in Table I. It will be seen that both test and control group results agree well with the normal figures of 5 to 7 i.u./1. for aspartate transaminase and 4 to 13

'The nomenclature in this article follows that recommended by the International Union of Biochemistry (1961) in the Report of the Commission on Enzymes.

Received for publication 16 July 1963.
TABLE I

LEVELS OF SERUM ALANINE AND ASPARTATE TRANSAMINASE IN TEST AND CONTROL GROUPS

\begin{tabular}{|c|c|c|c|c|}
\hline & \multicolumn{2}{|c|}{$\begin{array}{l}\text { Serum Alanine } \\
\text { Transaminase }\end{array}$} & \multicolumn{2}{|c|}{$\begin{array}{l}\text { Serum Aspartate } \\
\text { Transaminase }\end{array}$} \\
\hline & Test & Control & Test & Control \\
\hline $\begin{array}{l}\text { Mean } \\
\text { Standard deviation } \\
\text { Range (i.u./l.) }\end{array}$ & $\begin{array}{l}6 \cdot 8 \\
1 \cdot 9 \\
3 \cdot 0-10 \cdot 6\end{array}$ & $\begin{array}{l}5 \cdot 5 \\
2 \cdot 2 \\
1 \cdot 0-9 \cdot 9\end{array}$ & $\begin{array}{l}11 \cdot 1 \\
2 \cdot 5 \\
6 \cdot 2-16 \cdot 0\end{array}$ & $\begin{array}{l}9 \cdot 8 \\
2 \cdot 0 \\
6 \cdot 9-11 \cdot 6\end{array}$ \\
\hline
\end{tabular}

i.u./l. for alanine transaminase quoted by Baron (1963), and there seems to be no significant difference between the results in either group.

The mean blood lead concentration for the leadexposed group was $0.42 \mu \mathrm{g}$. $/ \mathrm{ml}$. (range 0.1 to 2.29 $\mu \mathrm{g} . / \mathrm{ml}$.$) , nine workers (19.5 \%)$ having a blood lead level above $0.8 \mu \mathrm{g} . / \mathrm{ml}$. The mean for the control group was $0.16 \mu \mathrm{g} . / \mathrm{ml}$. (range 0 to $0.63 \mu \mathrm{g} . / \mathrm{ml}$.).

The range of blood lead found by Waldman and Borman (1959) was 0.2 to $1.4 \mu \mathrm{g}$./g. No details of length of exposure to lead were given, although it was reported that none of the persons examined demonstrated clinical symptoms of plumbism.

In none of the lead workers examined in the present series were the levels of either serum aspartate or alanine transaminase raised, and no correlation at all was observed between these levels and the blood lead concentration.

My thanks are due to Dr. A. J. de Kretser for his help and to Dr. A. R. Thompson and the Management of Vauxhall Motors Ltd., for permission to publish this paper.

\section{REFERENCES}

Baron, D. N. (1963). Proc. roy. Soc. Med., 56, 173.

Casula, D., Cherchi, P., Piredda, S., and Spinazzola, A. (1959). Rass. med. sarda., 61, 839

International Union of Biochemistry. (1961). Report of the Commission on Enzymes, New York. (Symposium Series, vol. 20.)

King, E., and Thompson, A. R. (1961). Ann. occup. Hyg., 3, 247.

Reitman, S., and Frankel, S. (1957). Amer. J. clin. Path., 28, 56.

Waldman, R. K., and Borman, E. K. (1959). A. M. A. Arch. industr. Hlth, 13, 431. 